\title{
The prevalence of the duodenal ulcer promoting gene (dupA) in Helicobacter pylori isolates varies by ethnic group and is not universally associated with disease development: a case-control study
}

\author{
Heather-Marie A Schmidt ${ }^{1}$, Sönke Andres ${ }^{2,3}$, Nadeem O Kaakoush ${ }^{1}$, \\ Lars Engstrand ${ }^{2,3}$, Lena Eriksson ${ }^{3}$, Khean-Lee Goh ${ }^{4}$, Kwong Ming Fock ${ }^{5}$, \\ Ida Hilmi ${ }^{4}$, Subbiah Dhamodaran ${ }^{5}$, David Forman ${ }^{6}$ and Hazel Mitchell*1
}

\begin{abstract}
Address: ${ }^{1}$ School of Biotechnology and Biomolecular Sciences, University of New South Wales, NSW, Sydney, Australia, ${ }^{2}$ Department of Microbiology, Tumor and Cell Biology, Karolinska Institutet, Stockholm, Sweden, ${ }^{3}$ Department of Bacteriology, Swedish Institute for Infectious Disease Control, Solna, Sweden, ${ }^{4}$ Department of Medicine, Faculty of Medicine, University of Malaya, Kuala Lumpur, Malaysia, ${ }^{5}$ Division of Gastroenterology, Department of Medicine, Changi General Hospital, Singapore and ${ }^{6}$ Centre for Epidemiology and Biostatistics, Faculty of Medicine and Health, Leeds University, Leeds, UK

Email: Heather-Marie A Schmidt - heather-marie.schmidt@student.unsw.edu.au; Sönke Andres - sonke.andres@smi.se; Nadeem O Kaakoush - nadok5@gmail.com; Lars Engstrand - lars.engstrand@smi.se; Lena Eriksson - lena.eriksson@smi.se; KheanLee Goh - klgoh56@tm.net.my; Kwong Ming Fock - Kwong_Ming_Fock@cgh.com.sg; Ida Hilmi - Ihilmi@tm.net.my; Subbiah Dhamodaran - S_Dhamodaran@cgh.com.sq; David Forman - D.Forman@leeds.ac.uk; Hazel Mitchell* - h.mitchell@unsw.edu.au * Corresponding author
\end{abstract}

\section{Published: II March 2009}

Gut Pathogens 2009, I:5 doi:10.1/86/1757-4749-1-5

This article is available from: http://www.gutpathogens.com/content/l/l/5

(c) 2009 Schmidt et al; licensee BioMed Central Ltd.

This is an Open Access article distributed under the terms of the Creative Commons Attribution License (http://creativecommons.org/licenses/by/2.0), which permits unrestricted use, distribution, and reproduction in any medium, provided the original work is properly cited.
Received: 20 January 2009

Accepted: II March 2009

\begin{abstract}
Background: The putative $H$. pylori pathogenicity-associated factor dupA has been associated with IL-8 induction in vitro, and duodenal ulcer (DU) and gastric cancer (GC) development in certain populations, but this association is inconsistent between studies. We aimed to investigate dupA prevalence in clinical isolates from Sweden, Australia and from ethnic Chinese, Indians and Malays resident in Malaysia and Singapore and to examine the association with DU and GC. In addition we investigated the sequence diversity between isolates from these diverse groups and compared the level of IL-8 secretion in isolates possessing and lacking dupA.
\end{abstract}

Methods: PCR primers were designed to amplify over the $\mathrm{C} / \mathrm{T}$ insertion denoting a continuous dupA. PCR products from 29 clinical isolates were sequenced and compared with sequences from three additional strains obtained from GenBank. Clinical isolates from 2I Malaysian patients (8 dupA-positive, 14 dupA-negative) were assessed for their ability to induce IL-8 in AGS cells in vitro. Statistical analysis was performed using Fisher's exact test.

Results: The prevalence of dupA in isolates from Swedish functional dyspepsia (FD) control patients $(65 \%, 13 / 20)$ was higher and in isolates from Indian FD patients $(7.1 \%, 3 / 42)$ was lower as compared with isolates from Chinese $(28.9 \%, 13 / 49, \mathrm{P}=0.005, \mathrm{P}=0.025)$, Malay $(35.7 \%, 5 / 14, \mathrm{P}=$ $0.16, \mathrm{P}=0.018)$ and Australian $(37.8 \%, 17 / 45, \mathrm{P}=0.060, \mathrm{P}<0.001) \mathrm{FD}$ patients. dupA was associated with DU and GC development in Chinese with $62.5 \%(10 / 16)$ and $54.6 \%(12 / 22)$ of isolates possessing dupA respectively as compared with $F D$ controls $(28.9 \%)(P=0.015, P=0.032)$. No significant difference in prevalence of dupA between FD controls, DU $(63.6 \%, 7 / \mathrm{II})$ and GC 
$(61.9 \%, 13 / 21)$ cases $(P=1.000)$ was observed in the Swedish population. Sequence analysis revealed a pairwise variation of $1.9 \%$ and all isolates possessed the $\mathrm{C} / \mathrm{T}$ insertion. The average IL8 induction was $1330 \mathrm{pg} / \mathrm{mL}$ for dupA-positive isolates and $1378 \mathrm{pg} / \mathrm{mL}$ for dupA-negative isolates.

Conclusion: Although dupA is highly conserved when present, we identified no consistent association between dupA and DU or GC development across the ethnic groups investigated, with the dupA prevalence in control groups varying significantly. Our results would suggest that in the clinical isolates investigated dupA is not associated with IL-8 induction in vitro.

\section{Introduction}

Although Helicobacter pylori infection invariably results in gastritis, a significant minority of those infected will progress to more severe gastroduodenal pathologies, including Duodenal Ulcer (DU) and Gastric Cancer (GC). The factors resulting in progression to severe H. pylorirelated disease are poorly understood, however there is compelling evidence to suggest a co-contribution of bacterial virulence factors, host genetics and environmental stimuli [1].

To date a number of $H$. pylori pathogenicity-associated factors, including flagella, adhesins, urease, the vacuolating cytotoxin and the cag pathogenicity island (cag PAI) have been associated with the development of more serious $H$ pylori-related disease outcomes. The cag PAI encodes a type IV secretion system (TFSS), homologous to the wellstudied virB/D4 TFSS of the plant pathogen Agrobacterium tumefaciens, as well as the effector protein CagA [2,3]. Translocation of CagA by the TFSS into gastric epithelial cells has been shown to drive deregulation of intracellular signaling pathways resulting in a myriad of cellular effects such as increased motility and elongation [4]. In a process independent of CagA, the TFSS also induces the production of the chemo-attractant and pro-inflammatory cytokine IL-8 by facilitating the entry of peptidoglycan into the host epithelial cell [5]. In vitro studies have demonstrated that the virB4 homologous ATPase, CagE (HP0544, JHP0492), is essential for IL-8 induction [6-10]. In addition to cagE, multiple virB4 homologues exist within the $H$. pylori genome, with both sequenced strains J99 and 26695 possessing three additional virB4 homologues $[11,12]$. Recently Lu et al. demonstrated that the partial virB4 homologues JHP0917 and JHP0918, which are present in the plasticity zone of J99 but not 26695 , form one continuous gene in clinical isolates the duodenal ulcer promoting gene $(d u p A)$. and that this gene was a functional virB4 homologous ATPase [13]. dupA, like $c a g E$, is associated with IL-8 induction [13] and thus it is possible that this may be part of an as yet unidentified TFSS. In the original study examining the role of $d u p A$ in more severe $H$. pylori related disease, $d u p A$ possessing isolates were found to be associated with the development of DU in patients from Columbia, Japan and Korea [13]. In contrast no association was found with gastric cancer sug- gesting that $d u p A$, and the TFSS it is associated with, may be a major determinant in DU-development. In contrast, two recent studies, one in Brazil [14] and a second in which subjects from Belgium, China, South Africa and the USA were examined [15] did not find an association between $d u p A$ and DU development. Given that $H$. pylori pathogenicity-associated factors in isolates from different populations have been shown to possess distinct genotypes [16-18], it is important that the association between a newly identified putative pathogenicity-associated factor, such as $d u p A$ and specific disease outcomes, be assessed in clinical isolates from a range of different regions and ethnic groups [19].

In the present study we determined the prevalence of $d u p A$ across a range of countries and ethnic groups including Australia, Sweden and the three primary ethnic groups resident within Malaysia, namely Chinese, Indians and Malays and examined the relationship between $d u p A$ and DU and GC in the Swedish and ethnic Chinese populations. We also sequenced $d u p A$ PCR products from isolates from each ethnic and disease group and determined that they possessed the $\mathrm{C} / \mathrm{T}$ insertion required for a continuous $d u p A$ gene, and additionally that there was a only a small degree of sequence diversity between isolates. Finally, we determined that the induction of IL- 8 secretion by AGS cells was not associated with the presence of $d u p A$ in the clinical isolates investigated in vitro.

\section{Methods}

Patients, H. pylori strains and extraction of genomic DNA Malaysian \& Singaporean

As part of a larger study examining the role of bacterial, host and environmental factors in GC development, gastric biopsies were obtained from consecutively enrolled unrelated patients undergoing routine endoscopic examination of gastrointestinal symptoms at the University Hospital, Kuala Lumpur, Malaysia and the Changi Hospital, Singapore (between mid-2004 and 2007). Based on endoscopic and histological examination, patients were diagnosed with either distal GC or functional dyspepsia (FD). Gastric biopsies were stored at $-70^{\circ} \mathrm{C}$ in brain heart infusion (BHI) broth containing 20\% glycerol and transported to Australia on dry ice. Gastric biopsies were smeared onto campylobacter selective medium (CSA), 
incubated and identified using morphology, microscopy and biochemical tests as previously described $[20,21]$. Genomic DNA from one single colony isolate per patient was extracted using the Gentra Puregene DNA extraction kit (Gentra, Minneapolis, Minnesota, USA). In the present study, 142 single colony isolates from 52 Chinese, 42 Indian and 14 Malay FD patients, 22 Chinese GC patients, and 16 Chinese DU patients were included.

\section{Swedish}

In a previous case-control study which recruited patients from eight hospitals in Sweden biopsies were collected, cultured for $H$. pylori and bacterial DNA extracted as previously described [22]. In the present study 52 single colony isolates from Swedish patients diagnosed with FD (20), DU (11) and GC (21) were included.

\section{Australian}

In a previous study which recruited patients from Sydney, Australia, biopsies were collected, cultured for $H$. pylori and bacterial DNA extracted as previously described [23]. In the present study, 45 single colony isolates from Caucasian Australian patients with FD were included.

\section{Primer design and detection of dupA in single colony isolates}

Primer pair dupA1274F and $d u p A 1674 R$ (table 1) were designed to amplify a 399-400 bp fragment corresponding to nucleotides 1016315-1016714 in J99 (accession no. AE001439). The PCR primers amplified over the region of $d u p A$ containing the 1 bp insertion/deletion detected by Lu et al. 2005 [13], that is the forward primer bound to a sequence from JHP0917 and the reverse primer bound to a sequence from JHP0918, suggesting that PCR positive isolates have both JHP0917 and JHP0918. PCR was performed in a $25 \mu \mathrm{L}$ reaction containing 0.825 U Taq DNA polymerase (Fisher Biotech, Subiaco, Australia), $45 \mathrm{nmol}$ magnesium-chloride, $10 \mathrm{pmol}$ of each primer and $10 \mathrm{ng}$ of genomic DNA. All PCR runs included a negative control (no DNA) and a positive control (J99). PCR was performed as follows: initial denatur- ation for 5 minutes at $95^{\circ} \mathrm{C}$, followed by 35 cycles of $95^{\circ} \mathrm{C}$ for 20 seconds, $55^{\circ} \mathrm{C}$ for 20 seconds and $72^{\circ} \mathrm{C}$ for 40 seconds, and a final at $72^{\circ} \mathrm{C}$ for 7 minutes. PCR products were visualized by agarose gel electrophoresis.

\section{Validation of primers and investigation of dupA by DNA sequencing}

29 single colony isolates (4 Chinese, 2 Indian, 4 Malay, 3 Australian and 3 Swedish FD isolates, 4 Chinese and 3 Swedish DU isolates, and 3 Chinese and 3 Swedish GC isolates) were sequenced to validate the specificity of the primers $d u p A F$ and $d u p A \mathrm{R}$ and to ascertain whether JHP0917-0918 formed a single continuous gene in these isolates. Sequencing was performed using the BigDye ${ }^{\mathrm{TM}}$ Terminator version 3.1 (Applied Biosystems, Foster City, California, USA). Sequencing analysis was performed on an ABI3730 Capillary DNA sequencer (GENterprise, Mainz, Germany). Sequences were verified using Blast [24] available from Biomanager by ANGIS http:// www.angis.org.au. Sequence alignments of the 29 strains, with the original $d u p A$ gene sequence from Gene Bank (accession no. AB196363) [13] and two additional $d u p A$ like sequences (accession no. EF076755 and EF076756) available in the GenBank database http:// www.ncbi.nlm.nih.gov/Genbank/index.html were created using ClustalW accurate [25] also available from BioManager.

\section{Development of a dupA multiplex PCR}

To confirm that isolates negative for the $d u p A$ PCR truly lacked the $d u p A$ gene, rather than being the result of sequence diversity over the primer annealing site, a multiplex PCR was designed involving the use of 2 forward (dupA113F and dupA1274F) and 3 reverse (dupA1083R, $d u p A 1674 \mathrm{R}$ and $d u p A 1830 \mathrm{R}$ ) primers which produce 5 differently sized PCR products if all primers bind (Figure 1). Primer sequences are presented in table 1.

The PCR was performed in a $25 \mathrm{uL}$ reaction as described above, with an initial denaturation for 5 minutes at $95^{\circ} \mathrm{C}$, followed by 35 cycles of $95^{\circ} \mathrm{C}$ for 30 seconds, $50^{\circ} \mathrm{C}$ for 30

Table I: PCR primers used in this study.

\begin{tabular}{|c|c|c|}
\hline Primer name & Nucleotide sequence (5'-3') & Reference \\
\hline dupAII3F & GAC GAT TGA GCG ATG GGA ATA T & {$[15]$} \\
\hline dupA I083R & CTG AGA AGC CTT ATT ATC TTG TTG G & {$[15]$} \\
\hline dupA I274F & GCG TGA TCA ATA TGG ATG CTT TTG C & This study \\
\hline dupAI674R & TTG TCT GGC TCT CAT GTC CGT GTT G & This study \\
\hline dupAI830R & CTT CCT TAT AAG TTT CTT GGT TTG C & {$[15]$} \\
\hline
\end{tabular}




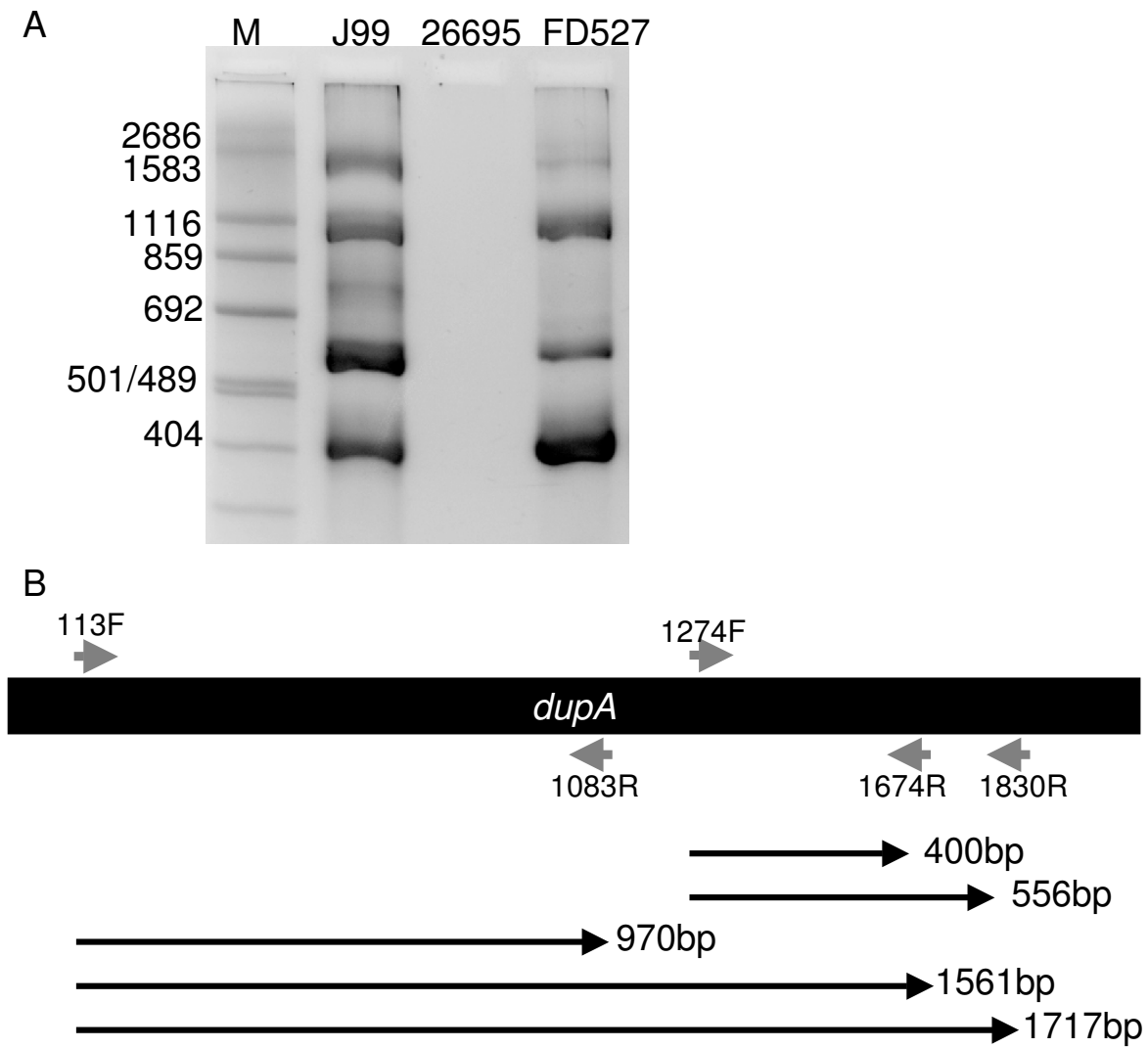

\section{Figure I}

PCR amplification using the dupA multiplex PCR. (A)Genomic DNA from H. pylori strains 599 (positive control), 26695 (negative control) and FD527 (clinical isolate) were used to PCR amplify dupA using the forward primers dupA / I3F and dupAI 274F, and the reverse primers dupAI083R, dupAI674R and dupAI830R. M, size markers (in base pairs). (B) Schematic representation of dupA showing the annealing positions of the forward primers dupA I I $3 \mathrm{~F}$ and dupAI274F, and the reverse primers dupA1083R, dupAI674R and dupA 1830R, and the expected sizes of the amplified PCR products.

seconds and $65^{\circ} \mathrm{C}$ for 2 minutes, and a final at $65^{\circ} \mathrm{C}$ for 7 minutes.

\section{Infection assay and IL-8 induction in vitro}

AGS cells (ATCC CRL-1739) were routinely maintained in RMPI1640 supplemented with 10\% FCS and glutamine (All from Gibco Invitrogen, Paisley, UK), and were cultured at $37^{\circ} \mathrm{C}$ in $5 \% \mathrm{CO}_{2} / 95 \%$ air. Cells were seeded in 24 well tissue culture plates and infected with approximately $3 \times 10^{7}$ bacterial cells. $22 \mathrm{H}$. pylori isolates from Malaysian patients ( $8 d u p A$-positive and $14 d u p A$-negative) were available for in vitro analysis. Two $H$. pylori control strains (67:20 (cag PAI negative) and 67:21 (cag PAI positive) [26] were also available for in vitro analysis. H. pylori isolates were cultured overnight in brucella broth (Sigma) supplemented with 5\% FCS (Gibco Invitrogen). Bacteria were added to AGS cells in duplicate, and were co-incubated for 6 hours before cell culture supernatant was collected and stored at $-20^{\circ} \mathrm{C}$ prior to use. At least three independent experiments were performed; results repre- sent the average for these experiments. The concentration of IL- 8 in the supernatant was analysed by ELISA, using the BD OptEIA: Human IL-8 ELISA set (BD, San Diego, CA, USA) according to the manufacturers instructions.

\section{Statistical Analysis}

Fisher's exact test was used to calculate statistical significance; two-sided P values $<0.05$ were considered significant.

Sequences have been deposited in GenBank under the following accession numbers: EU253504-EU253532.

\section{Results}

Prevalence of dupA

Following PCR analysis, dupA was identified in 15/52 (28.9\%) Chinese, 5/14 (35.7\%) Malay, 3/42 (7.1\%) Indian, $17 / 45$ (37.8\%) Australian and 13/20 (65.0\%) Swedish FD clinical isolates (table 2). The prevalence of $d u p A$ in Swedish FD isolates was higher $(\mathrm{P}=0.005, \mathrm{P}=$ 
Table 2: Comparison of dupA prevalence between ethnic groups and countries.

\begin{tabular}{|c|c|c|c|c|c|c|c|c|c|c|c|}
\hline & $\begin{array}{l}\text { Ethnicityl } \\
\text { Country }\end{array}$ & Australian & Chinese & & & & Indian & Malay & Swedish & & \\
\hline & Diagnosis & FD & FD & DU & GC & FD & FD & FD & DU & GC & \\
\hline Ethnicity & Diagnosis & $\begin{array}{l}\text { Prevalence } \\
\text { (\%) }\end{array}$ & 37.4 & 28.9 & 62.5 & 54.6 & 7.1 & 37.7 & 65.0 & 63.6 & 61.9 \\
\hline Australian & $\mathrm{FD}(\mathrm{n}=45)$ & 37.4 & $P=1.000$ & $P=0.237$ & & & $P<0.001$ & $P=1.000$ & $P=0.060$ & & \\
\hline \multirow[t]{3}{*}{ Chinese } & $\mathrm{FD}(\mathrm{n}=52)$ & 28.9 & $P=0.237$ & $P=1.000$ & $P=0.015$ & $P=0.032$ & $P=0.025$ & $P=0.052$ & $P=0.005$ & & \\
\hline & $D U(n=16)$ & 62.5 & & $P=0.015$ & $P=1.000$ & $P=0.744$ & & & & \multirow{2}{*}{$P=1.000$} & \\
\hline & $\mathrm{GC}(\mathrm{n}=22)$ & 54.6 & & $P=0.032$ & $P=0.744$ & $P=1.000$ & & & & & $P=0.760$ \\
\hline Indian & $\mathrm{FD}(\mathrm{n}=42)$ & 7.1 & $P<0.001$ & $P=0.025$ & & & $P=1.000$ & $P=0.018$ & $P<0.001$ & & \\
\hline Malay & $\mathrm{FD}(\mathrm{n}=14)$ & 37.7 & $P=1.000$ & $P=0.052$ & & & $P=0.018$ & $P=1.000$ & $P=0.163$ & & \\
\hline \multirow[t]{3}{*}{ Swedish } & $\mathrm{FD}(\mathrm{n}=20)$ & 65.0 & $P=0.060$ & $P=0.005$ & & & $P<0.001$ & $P=0.163$ & $P=1.000$ & $P=1.000$ & $P=1.000$ \\
\hline & $D U(n=11)$ & 63.6 & & & $P=1.000$ & & & & $P=1.000$ & $P=1.000$ & $P=1.000$ \\
\hline & $G C(n=21)$ & 61.9 & & & & $P=0.760$ & & & $P=1.000$ & $P=1.000$ & $P=1.000$ \\
\hline
\end{tabular}

Comparison of the prevalence of dupA-positive clinical isolates as determined by PCR between FD (functional dyspepsia), DU (duodenal ulcer) and GC (gastric cancer) patients from Australia, Sweden and the 3 primary ethnic groups of Malaysia and Singapore (Chinese, Indian and Malay). The statistical significance (P-values) of each valid comparison is displayed.

$0.162, \mathrm{P}=0.025)$ and the prevalence in Indian FD isolates was lower $(\mathrm{P}=0.025, \mathrm{P}=0.0517, \mathrm{P}=0.094)$ as compared with the Chinese, Malay and Australian FD isolates investigated. There was no significant difference in the prevalence of $d u p A$ between isolates from Chinese, Malay and Australian FD patients $(\mathrm{P}=0.052$ to $\mathrm{P}=1.000)$. Among isolates from Chinese or Swedish DU patients there was no significant difference between the two ethnicities, with $10 / 16(62.5 \%)$ and $7 / 11(63.6 \%)$ of the isolates possessing $d u p A$ respectively $(\mathrm{P}=1.000)$. Similarly, there was no significant difference between isolates from Chinese and Swedish GC patients with $12 / 22(54.6 \%)$ and $13 / 21$ $(61.9 \%)$ isolates possessing $d u p A$ respectively $(\mathrm{P}=0.759)$. Among isolates from Chinese patients, the prevalence of isolates possessing $d u p A$ was significantly higher in isolates from DU and GC patients than in isolates from FD control patients $(\mathrm{P}=0.015, \mathrm{P}=0.032)$, suggesting an association with the development of disease in this population. There was no significant difference in $d u p A$ prevalence between the isolates from Chinese DU and Chinese GC patients $(P=0.744)$. Conversely, there was no significant difference in the prevalence of $d u p A$ between isolates from Swedish FD, DU and GC patients $(\mathrm{P}=1.000)$.

\section{Sequence Analysis}

Blast analysis of sequences from 29 clinical isolates revealed significant sequence similarity to the $d u p A$ gene sequence deposited in GenBank, accession no. AB196363[13] and the sequence of a dupA-like protein with GenBank accession no. EF076755. Of the 4 Chinese, 2 Indian, 4 Malay FD, 3 Swedish FD and 3 Australian FD isolates, 4 Chinese and 3 Swedish DU isolates, and 3 Chinese and 3 Swedish GC isolates, all isolates were observed to possess a $1 \mathrm{bp} \mathrm{C}$ or T insertion after position 1385 relative to gene JHP0917 in J99 suggesting the presence of 1 continuous open-reading frame.

Sequence alignments from the 29 clinical isolates with 3 comparable sequences deposited in GenBank (AB196363, EF076755, EF076756) revealed that $d u p A$ possessed a pair-wise sequence variation of only $1.90 / 100 \mathrm{bp}$ (maximum variation: $14.71 / 100 \mathrm{bp}$, minimum variation $0.46 /$ $100 \mathrm{bp}$, median variation $0.92 / 100 \mathrm{bp}$, standard deviation 3.16/100 bp). Two isolates examined (the Chinese FD isolate FD553 (GenBank sequence: EU253520) and Iranian isolate EF076756), demonstrated a sequence variations of $14.71 / 100 \mathrm{bp}$ and $12.64 / 100 \mathrm{bp}$ respectively, being more than 2 standard variations above the mean. In the case of FD553 the high degree of sequence variation was the direct result of a $60 \mathrm{bp}$ insertion at base pair 1465 relative to $\underline{A B 196363}$. The remaining isolates were within 1 standard deviation of the mean.

\section{Multiplex PCR}

The use of the multiplex PCR revealed no additional isolates positive for $d u p A$, when compared to the use of $d u p A 1274 F$ and $d u p A 1674 R$ alone, suggesting that the use of the single primer pair is adequate to determine the prevalence of $d u p A$ in both western and east Asian popu- 
lations. An example of the multiplex PCR is presented in figure 1; all five bands are clearly distinguishable in clinical isolate FD527.

\section{In vitro IL-8 production}

The uninoculated control secreted $13 \mathrm{pg} / \mathrm{ml}$, with the negative control strain (67:20) secreting $80 \mathrm{pg} / \mathrm{ml}$ and the positive control strain (67:21) secreting $1368 \mathrm{pg} / \mathrm{ml}$ (figure $2 \mathrm{~A})$. Individual IL-8 secretion levels varied between $126 \mathrm{pg} / \mathrm{ml}$ and $1855 \mathrm{pg} / \mathrm{ml}$ for $d u p A$-positive isolates, and $123 \mathrm{pg} / \mathrm{ml}$ and $1633 \mathrm{pg} / \mathrm{ml}$ for dupA-negative isolates. However, no significant difference $(\mathrm{p}>0.5)$ was observed in the average level of IL- 8 secreted by AGS cells between clinical isolates possessing $d u p A(1330 \mathrm{pg} / \mathrm{mL})$ and those lacking $d u p A(1378 \mathrm{pg} / \mathrm{mL}$ ) (figure $2 \mathrm{~B}$ ).

\section{Discussion}

The current investigation of the prevalence of $d u p A$ in clinical isolates from Australia and Sweden as well as from the three major ethnic groups (Chinese, Indians and Malays) resident in Malaysia and Singapore clearly shows that there is significant variability in the prevalence of $d u p A$ between not only geographical locations, but also between ethnic groups resident in the same country. In the present study the prevalence of $d u p A$ in $H$. pylori isolates collected from FD patients varied significantly between nationalities/ethnicities, with isolates from Swedish patients being significantly more likely to possess $d u p A(65.0 \%)$ than isolates from Australia (26.3\%) or ethnic Chinese $(28.9 \%)$, Indians $(7.1 \%)$ or Malays $(35.7 \%)$ resident in Malaysia or Singapore. Interestingly isolates from ethnic Indian FD patients were significantly less likely to possess $d u p A(7.1 \%)$ than isolates from any of the other groups. This difference in $d u p A$ prevalence between countries and ethnic groups is supported by several studies [15,27] including the initial Lu et al. 2005 [13] which identified that $d u p A$ was more prevalent in isolates from Columbian gastritis patients (39\%) than in isolates from Japanese (14\%) and Koreans (7\%) gastritis patients. Furthermore, there is no significant difference in $d u p A$ prevalence reported previously for isolates from Chinese patients (25\% and 35.3\% respectively) [15,28] and for isolates from ethnic Chinese Malaysians and Singaporeans reported in the present study $(28.9 \%)$, despite different primer pairs being used, suggesting that the primer pair designed in this study is appropriate. Conversely, the prevalence reported in a north Indian population was considerably higher than that found in the ethnic Indian Malaysians in the present study (16/70 as compared with 3/42) [29]. One possible explanation is that the Indian Malaysians are likely to be predominantly ethnic Tamil [29], originating from Southern India, rather than the north Indian Indeed, two studies in Brazil reported significantly different prevalences for $d u p A$ (92.3\% vs. 62\%) $[14,30]$.

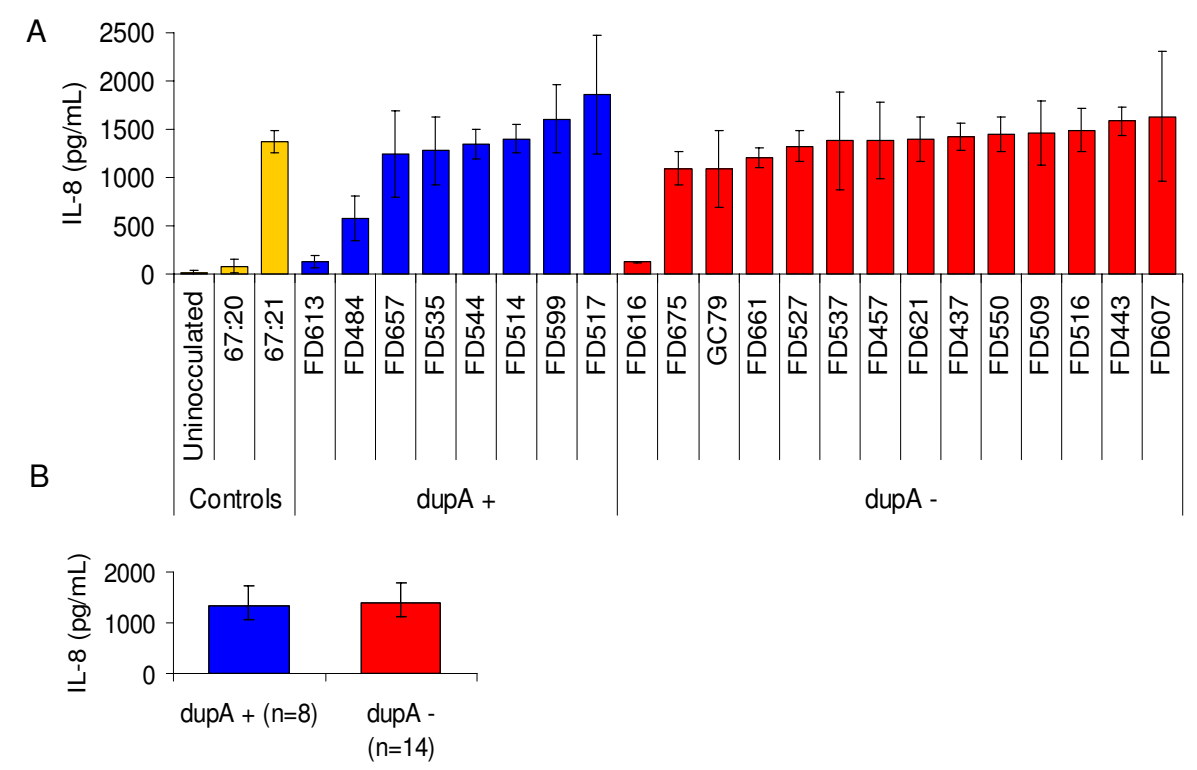

Figure 2

IL-8 induction in AGS cells by clinical isolates in vitro. (A) Induction of IL-8 secretion in AGS cells incubated with indicated strains for 6 hours. The error bars show the standard deviations of each independent experiment. (B) Average induction of IL-8 secretion in AGS cells incubated with dupA positive (blue) or negative (red) strains. The error bars show the standard deviations for each group of strains. 
We also demonstrated that the association between $d u p A$ and severe gastroduodenal disease was inconsistent between the Chinese and Swedish populations. In isolates from ethnic Chinese patients the prevalence of $d u p A$ was significantly higher in patients diagnosed with DU $(62.5 \%)$ or GC $(54.6 \%)$ as compared with those diagnosed with FD. This is in contrast to the observations of Lu et al. 2005 [13] and Zhang et al. 2008 [28] who reported a negative association with GC, but supports the observations by Argent et al. [15]. In contrast, in the Swedish population there was no significant difference in the prevalence of $d u p A$ in isolates from patients diagnosed with DU, GC or FD, similar to findings reported from Brazil $[14,30]$. Our observations are consistent with the reported variation in other $H$. pylori virulence factors such as the cagA and $v a c A$ genes [31], and further emphasise the fact that before a new virulence factor is associated with a specific disease outcome, studies must be undertaken in a range of geographic locations as well in different ethnic groups.

Lu et al. have reported that, with the exception of J99, JHP0917-JHP0918 forms a continuous open reading frame, $d u p A$, due to the presence of a $1 \mathrm{bp} \mathrm{C/T}$ insertion in clinical isolates [13]. In the present study, all clinical isolates sequenced possessed a continuous $d u p A$ gene, signified by the presence of the $\mathrm{C} / \mathrm{T}$ insertion, a finding that is consistent with previous reports in other populations $[13,14,32]$. Our results also indicate that $d u p A$ is highly conserved over the region sequenced with an average partial sequence variation of only $1.9 \%$. This indicates a high degree of conservation comparable to housekeeping genes such as atpA, ureI, efp, and ppa [33]. We must acknowledge that as only 29 clinical isolates were sequenced and the sequences used for comparison represent less than $400 \mathrm{bp}$, the pairwise sequence variation for the entire gene and in a larger population may be higher than that described here. Interestingly in a recent study Douraghi et al. compared 3 regions of the $d u p A$ gene JHP0917 (289 bp), JHP0918 (259 bp) and the junction region over JHP0917 and JHP0918 i.e. 'dupA' (216 bp) in 6 Iranian strains with that of 10 Brazilian and 3 Indian strains whose sequences had been deposited in GenBank [32]. The reported sequence similarities in that study ranged from $86.1 \%-100 \%$ for JHP0917, $88-98.8 \%$ for JHP0918 and $93.4-99.5 \%$ for 'dupA, a finding that would support the high degree of conservation of this gene observed in our study. Surprisingly in the Douraghi et al. study none of the strains were compared for all 3 regions.

The high degree of sequence conservation reported and the finding that $d u p A$ is present in strains from different continents and in populations with different genetic backgrounds, suggests that $d u p A$ may confer a fitness advantage of some sort, which has resulted in the conservation of the gene and the sequence, throughout human migra- tion. An alternate explanation, since $d u p A$ is located in the plasticity zone, is that the acquisition was a relatively recent phenomenon. Although there is, as yet, no specific evidence for either scenario, we believe the former explanation is more likely. Whole gene sequence analysis of dupA over an increased sample size is necessary to adequately investigate these points.

Although the initial study by Lu et al reported that $d u p A$ was associated with IL-8 induction in vitro in both knockout studies and in clinical isolates [13], in the present study we observed no significant difference in the level of IL-8 induction between strains with or without $d u p A$. It is possible however that the strains used in the present study lacked the other essential components of the dupA type IV secretion system, however, as none of these components have yet been identified it is impossible to assess whether this is responsible for the lack of association with IL-8 induction in the present study. More comprehensive studies with strains lacking genes known to contribute to IL-8 induction such as cag PAI components and with oipA off would be beneficial in elucidating the contribution of $d u p A$ to IL-8 induction.

\section{Conclusion}

Although based on our findings and those of others, it is unlikely that $d u p A$ is itself a determinant or indicator of a specific clinical outcome across all populations; it may be shown to be an important virulence factor if a role as part of a novel TFSS is identified.

\section{Competing interests}

The authors declare that they have no competing interests.

\section{Authors' contributions}

HMAS designed the study, prepared the Malaysian isolates for analysis, designed and carried out the molecular genetic studies, carried out the sequence alignment and analysis, performed the statistical analysis, helped design and participated in the in vitro studies and drafted the manuscript. SA helped design and participated in the in vitro studies. NK participated in the molecular genetic studies. LEr prepared the Swedish isolates for analysis. HM was awarded grant to support the study, participated in the design of the study and helped to draft the manuscript. All authors read and approved the final manuscript.

\section{Acknowledgements}

This work was supported by The Cancer Council of New South Wales, Australia (REF 66/04). Sönke Andres was supported by a grant from the Marie Curie Early Stage Research Training Fellowship of the European Community's Sixth Framework Program called IMO-train.

We would like to thank Alfred Tay for providing the calculations on the pairwise sequence variation for the Falush et al. [33] study. We would also like to thank Quanjiang Dong for his help with primer design. 


\section{References}

I. Pritchard DM, Crabtree JE: Helicobacter pylori and gastric cancer. Curr Opin Gastroenterol 2006, 22:620-625.

2. Odenbreit S, Puls J, Sedlmaier B, Gerland E, Fischer W, Haas R: Translocation of Helicobacter pylori CagA into gastric epithelial cells by type IV secretion. Science 2000, 287: I497-I 500.

3. Backert S, Ziska E, Brinkmann V, Zimny-Arndt U, Fauconnier A, Jungblut PR, Naumann M, Meyer TF: Translocation of the Helicobacter pylori CagA protein in gastric epithelial cells by a type IV secretion apparatus. Cell Microbiol 2000, 2: I55-I64.

4. Backert S, Selbach M: Role of type IV secretion in Helicobacter pylori pathogenesis. Cell Microbiol 2008, I 0:I573-I58I.

5. Viala J, Chaput C, Boneca IG, Cardona A, Girardin SE, Moran AP, Athman $\mathrm{R}$, Mémet $S$, Huerre MR, Coyle AJ, et al.: Nod I responds to peptidoglycan delivered by the Helicobacter pylori cag pathogenicity island. Nat Immunol 2004, 5: I I66-I I74.

6. Maeda S, Ogura K, Yoshida H, Kanai F, Ikenoue T, Kato N, Shiratori Y, Omata M: Major virulence factors, VacA and CagA, are commonly positive in Helicobacter pylori isolates in Japan. Gut 1998, 42:338-343.

7. Owen RJ, Sharp S, Lawson AJ, Durrani Z, Rijpkema S, Kidd M: Investigation of the biological relevance of Helicbacter pylori cagE locus diversity, presence of CagA motifs and vacuolating cytotoxin genotype on IL-8 induction in gastric epithelial cells. FEMS Immunol Med Microbiol 2003, 36: I35-| 40.

8. Tummuru MK, Sharma SA, Blaser MJ: Helicobacter pylori picB, a homologue of the Bordetella pertussis toxin secretion protein, is required for induction of IL-8 in gastric epithelial cells. Mol Microbiol 1995, I 8:867-876.

9. Day AS, Jones NL, Lynett JT, Jennings HA, Fallone CA, Beech R, Sherman PM: cagE is a virulence factor associated with Helicobacter pylori-induced duodenal ulceration in children. I Infect Dis 2000, | 8 | : | 370- | 375

10. Censini S, Lange C, Xiang Z, Crabtree JE, Ghiara P, Borodovsky M, Rappuoli R, Covacci A: cag, a pathogenicity island of Helicobacter pylori, encodes type I-specific and disease associated virulence factors. Proc Natl Acad Sci USA 1996, 93: | 4648-| 4653

II. Alm RA, Ling LS, Moir DT, King BL, Brown ED, Doig PC, Smith DR, Noonan B, Guild BC, dejonge BL, et al.: Genomic-sequence comparison of two unrelated isolates of the human gastric pathogen Helicobacter pylori. Nature 1999, 397: I76- 180.

12. Tomb J-F, White O, Kerlavage AR, Clayton RA, Sutton GG, Fleischmann RD, Ketchum KA, Klenk HP, Gill S, Dougherty BA, et al:: The complete genome sequence of the gastric pathogen Helicobacter pylori. Nature 1997, 388:539.

13. Lu H, Hsu P-I, Graham D, Yamaoka Y: Duodenal ulcer promoting gene of Helicobacter pylori. Gastroenterol 2005, I 28:833-848.

14. Gomes LI, Rocha GA, Rocha AM, Soares TF, Oliveira CA, Bittencourt PF, Queiroz DM: Lack of association between Helicobacter pylori infection with dupA-positive strains and gastroduodenal diseases in Brazilian patients. Int J Med Microbiol 2008 , 298:223-230.

15. Argent RH, Burette A, Miendje Deyi VY, Atherton JC: The presence of dupA in Helicobacter pylori is not significantly associated with duodenal ulcer in Belgium, South Africa, China or North America. Clin Infect Dis 2007, 45: I 204- 1206.

16. Miehlke S, Kibler K, Kim JC, Figura N, Small SM, Graham DY, Go MF: Allelic variation in the cagA gene of Helicobacter pylori obtained from Korea compared to the United States. Am J Gastroenterol 1996, 91:1322-1325.

17. Cao P, Lee KJ, Blaser MJ, Cover TL: Analysis of hopQ alleles in East Asian and Western strains of Helicobacter pylori. FEMS Microbiol Lett 2005, 25 I:37-43.

18. Tan HJ, Rizal AM, Rosmadi MY, Goh KL: Distribution of Helicobacter pylori cagA, cagE and vacA in different ethnic groups in Kuala Lumpur, Malaysia. J Gastroenterol Hepatol 2005, 20:589-594

19. Lu H, Yamaoka Y, Graham DY: Helicobacter pylori virulence factors: facts and fantasies. Curr Opin Gastroenterol 2005, 2 I :653-659.

20. Lee A, O'Rourke J, Ungria MCD, Robertson B, Daskalopoulos G, Dixon MF: Erratum: a standardized mouse model of Helicobacter pylori infection - introducing the Sydney strain. Gastroenterol 1997, I 1 3:732.

21. Lee A, O'Rourke J, Ungria MCD, Robertson B, Daskalopoulos G Dixon MF: A standardized mouse model of Helicobacter pylori infection - introducing the Sydney strain. Gastroenterol 1997, I | 2: 1386- I397.

22. Enroth H, Kraaz W, Engstrand L, Nyrén O, Rohan T: Helicobacter pylori strain types and risk of gastric cancer: a case-control study. Cancer Epidemiol Biomarkers Prev 2000, 9:98I-985.

23. Borody T, Clancy R, Warren EF, Surace R, Brusentsev S, Mitchell H: Antibiotic sensitivities of Helicobacter pylori vary at different gastric mucosal sites. In Helicobacter pylori: Basic mechanisms to clinical cure 2002 Edited by: Hunt R, Tytgat G. Dordrecht: Kluwer Academic Publishers; 2003:373-382.

24. Altschul SF, Madden TL, Schäffer AA, Zhang J, Zhang Z, Miller W, Lipman D): Gapped BLAST and PSI-BLAST: a new generation of protein database search programs. Nucl Acids Res 1997 25:3389-3402.

25. Thompson JD, Higgins DG, Gibson TJ: CLUSTAL W: improving the sensitivity of progressive multiple sequence alignment through sequence weighting, position-specific gap penalties and weight matrix choice. Nucl Acids Res 1994, 22:4673-4680.

26. Bjorkholm B, Lundin A, Sillen A, Guillemin K, Salama N, Rubio C, Gordon Jl, Falk P, Engstrand L: Comparison of genetic divergence and fitness between two subclones of Helicobacter pylori. Infect Immun 200I, 69:7832-7838

27. Hussein $N$, Mohammadi $M$, Talebkhan $Y$, Doraghi $M$, Letley $D$, Muhammad M, Argent R, Atherton J: Differences in virulence markers between Helicobacter pylori strains from Iraq and those from Iran: potential importance of regional differences in H. pylori-associated disease. J Clin Microbiol 2008, 46:1774-1779.

28. Zhang Z, Zheng Q, Chen X, Xiao S, Liu W, Lu H: The Helicobacter pylori duodenal ulcer promoting gene, dupA, in China. BMC Gastroenterol 2008, 8:49.

29. Arachchi HS, Kalra V, Lal B, Bhatia V, Baba CS, Chakravarthy S Rohatgi S, Sarma PM, Mishra V, Das B, Ahuja V: Prevalence of duodenal ulcer promoting gene (dupA) of Helicobacter pylori in patients with duodenal ulcer in north Indian population. Helicobacter 2007, I 2:591-597.

30. Pacheco AR, Proença-Módena JL, Sales AI, Fukuhara Y, Silveira WDd, Pimenta-Módena JL, Oliveira RBd, Brocchi M: Involvement of the Helicobacter pylori plasticity region and cag pathogenicity island genes in the development of gastroduodenal diseases. Eur J Clin Microbiol Infect Dis 2008, 27:1053-1059.

31. Ahmed N, Sechi LA: Helicobacter pylori and gastroduodenal pathology: new threats from an old friend. Ann Clin Microbiol Antimicrob 2005, 4:I.

32. Douraghi M, Mohammadi M, Oghalaie A, Abdirad A, Mohagheghi M, Hosseini M, Zeraati H, Ghasemi A, Esmaieli M, Mohajerani N: dupA as a risk determinant in Helicobacter pylori infection. J Med Microbiol 2008, 57:554-562

33. Falush D, Wirth T, Linz B, Pritchard JK, Stephens M, Kidd M, Blaser M], Graham DY, Vacher S, Perez-Perez Gl, et al: Traces of human migrations in Helicobacter pylori populations. Science 2003 , 299: $1582-1585$

Publish with Bio Med Central and every scientist can read your work free of charge

"BioMed Central will be the most significant development for disseminating the results of biomedical research in our lifetime. "

Sir Paul Nurse, Cancer Research UK

Your research papers will be:

- available free of charge to the entire biomedical community

- peer reviewed and published immediately upon acceptance

- cited in PubMed and archived on PubMed Central

- yours - you keep the copyright 